\title{
Witnessing and Waiting in Walt Whitman's Democratic Arts of Attention
}

\author{
Alexander Keller Hirsch
}

check for

updates

Citation: Hirsch, Alexander Keller. 2021. Witnessing and Waiting in Walt Whitman's Democratic Arts of Attention. Humanities 10: 85 https://doi.org/10.3390/h10030085

Received: 8 May 2021

Accepted: 15 June 2021

Published: 25 June 2021

Publisher's Note: MDPI stays neutral with regard to jurisdictional claims in published maps and institutional affiliations.

Copyright: (C) 2021 by the author. Licensee MDPI, Basel, Switzerland. This article is an open access article distributed under the terms and conditions of the Creative Commons Attribution (CC BY) license (https:/ / creativecommons.org/licenses/by/ $4.0 /)$.
Department of Political Science, University of Alaska, Fairbanks, AK 99775, USA; ahirsch@alaska.edu

\begin{abstract}
What is often overstated by democratic theorists enthralled by the poetic vision of Walt Whitman is the extent to which he excised the self in order to exalt a world where the sensed and the sensing collapse into reversibility. Throughout "Song of Myself," I argue, Whitman experiments with an arts of attention-which he describes as "witnessing and waiting" - that adapts the self to the surplus vitality immanent to perceptual and sensual experience. I contrast this with democratic theories of "relational surrender" that stress self-sacrifice as the precondition for democratic sovereignty. In particular, I contrast Whitman's poetics of touch with Elaine Scarry's theory of beauty, which favors what she calls "opiated adjacency," a vivid pleasure experienced in self-loss. By contrast, Whitman discloses a vision of democracy that emphasizes "cleaving things asunder," a sense of intensified awareness that forms in spaces of proximity that are also spaces of separation.
\end{abstract}

Keywords: Whitman; democracy; waiting; witnessing; Deleuze; Scarry

\section{Introduction}

One popular view in contemporary political theorizing holds that democracy inheres in acts of generative self-shattering. According to this argument, democracy does not merely entail the mutual transferring of rights or, for that matter, the cultivation of institutions that facilitate the general will. Rather, democracy requires that citizens become profoundly dispossessed of their subjective anchoring. Anne Norton is exemplary in this regard: "Democracy requires that we encompass the possibility (even the enactment) of our own annihilation. Democracy requires that at some moments, and in some respects always, one will cease to be" (Norton 2001, p. 166). Participating in democracy, Norton argues, not only suggests that members act in concert to shape power, it also includes an undoing of the self, which must be "dissolved into a common matrix": "One will be not only ruled and overruled, but made absent" (Norton 2001, p. 166). This self-loss is not merely figurative for Norton. In accepting a democratic verdict that refuses one's self-interest, one forfeits not only the coordinates of that self-regard but also the primacy of the self on behalf of whom interest is nominally waged. Thus, democracy involves surrender to self-abeyance, to "the prospect of one's own annihilation, of aphasia, of nonbeing;" making "the practice of democracy the practice of loss" (Norton 2001, p. 166).

For others, this argument is grounded in the assumption that democracy is the political corollary to a lifeworld characterized by thick expressions of mutual active witnessing. Kaja Silverman writes of a democratic politics of analogy in which we are ontologically imbricated in one another's lives:

Each of us is connected through similarities that are neither of our making or our choosing to countless other beings. We cannot extricate ourselves from these relationships, because there is no such thing as an individual; the smallest unit of Being is two interlocking terms ... Analogy runs through everything-that-is like a shuttle through a loom, weaving its threads into the All ... Since analogy prevents similar things from collapsing into, and disparate things from going their separate ways, it is ontologically democratizing. (Silverman 2015, p. 11) 
For Silverman, the world itself is densely interwoven in a field of public flesh in which we are richly enfolded, and democracy is the political form that acknowledges this condition. ${ }^{1}$

In many ways, the poetry of Walt Whitman supports these views. In "Song of Myself," Whitman exhibits a world where singularities merge and respond in a "vast, interlocking similitude." To be "myself," sings Whitman, is to occupy an uncanny place, "for every atom belonging to me as good belongs to you." The poem signals the dreamy montage of a supple world held in common. In addition, it presents Whitman himself, "at no remove from life's immediacy," entangled within a fabulation of sensual intensities. In particular, "Song of Myself" hones what Whitman terms the "procreant urge of the world," a phrase that discloses the world's persistent impulse to bring into being new sources of creation. Whitman's account of awe and wonder, inspired by this procreant urge, is articulated through a poetics of worldly absorption. His exuberant vitalism has, for good reason, attracted a host of democratic theorists to his "poetry of equality," and especially to Whitman's great effort "to create a democratic countercosmos" (Nussbaum 2001, p. 656). ${ }^{2}$

As persuasive as these accounts have been, what is often overstated is the extent to which Whitman sacrificed the self in order to exalt the flux of a world where the sensed and the sensing collapse into reversibility. Throughout "Song of Myself," Whitman experiments with an arts of attention that adapts the reader to the "procreant urge of the world," in ways that do not abolish the sovereign self, so much as refract and expand it. This is articulated through passages that demonstrate a passionate clinging to sensual experience that nonetheless includes a parting, a "quivering away" from the self that takes place as one gets "filled up" with the trace of an excessive "too-muchness" left behind by such experiences. Drawing upon Gilles Deleuze's notion that in order to perceive fully one must "cleave things asunder," I argue that Whitman articulates a poetics of democratic cleaving, a sense of belonging to the world owing to an intensified awareness. For Whitman, this dilation of awareness is catalyzed by perceptual excitations that take shape in spaces of proximity that are also spaces of sundering.

Exploring affiliative cleaving as a site of democratic world making is a hallmark of Whitman's essays, in particular "Democratic Vistas," but I take my point of departure from Section 4 of "Song of Myself," where Whitman most clearly identifies his arts of attention as "witnessing and waiting." For Whitman, waiting is hardly about postponing or otherwise suspending action. Although Whitmanian witnessing does involve an egoistic drift, it would be unfair to characterize his practice as an "anti-intellectual pseudo-Zen valuation of immediacy over reflection" (Morton 2013). Instead, for Whitman, witnessing and waiting represent rich structures of attunement that consist in restlessly responding to a world that is clamoring to be noticed. Witnessing and waiting, for Whitman, entail being actively embedded in an intimate relation to the world's generous ways of happening. Through this experience, the self is unmade and remade again, cast off and returned, caught up in a dynamic energetics of perpetual loss and recreation ("Round and round we go, all of us,/and ever come back/thither"). For Whitman, perception and sensuality are not reactions or adjustments to physical stimuli. Rather, sensual experiences reflect the summoning hail of the procreant urge of the world. In particular, they signal the surplus pressure generated by a sensual world that produces more reality that can be contained or perceived. As such, I argue that Whitman's arts of attention-witnessing and waiting-animates the cleaving that forms the basis for democratic conviviality, embodied in particular, as shall be seen, by his poetics of touch.

I contrast my reading of Whitman's view with Elaine Scarry's defense of the delicate democratic link connecting self-abandonment and collective flourishing convoked by aesthetic experiences of beauty. For Scarry, being caught up, or "hailed," by beautiful objects prompts a sense of awe and even pleasure derived from one's own self-marginalization. In particular, beauty is adapted to the democratic condition of equitable distribution and "to fairness, not just in the sense of loveliness of aspect but in the sense of a symmetry of everyone's relation to one another" (Scarry 1999, p. 65). Scarry calls this "opiated adjacency," the pleasure-bearing pressure that quickens a concern for the welfare of others. 
According to my argument, Whitman's witnessing and waiting provides a way of viewing democracy as something more. Following a close reading of Whitman's arts of attention in the early passages of "Song of Myself", I argue that democracy calls on citizens to fashion an act of attention adapted to the world's surplus aliveness. Moreover, democracy commends its members to a profound sense of affiliative cleaving that goes beyond ecstatic disintegration or pleasurable self-loss. I argue that, in this sense, following Whitman, democracy is less vested in a project of self-sacrifice than it is comprised by acts of attention that underscore the double valence of being at once "myself" and yet comprised of elements not of my making. Thus, democracy is not a practice of loss. Nor is it vested in a vision of worldly flushness. Rather, democracy is an exercise in cleaving things asunder, and witnessing and waiting in Whitman's arts of attention can be seen as the key to unlocking this insight. There is an element of tragic pragmatism to this, but in its celebration of the world's procreant urge, Whitman's poetry expresses more life than loss. ${ }^{3}$

\section{Witness and Wait}

In "Song of Myself", description is never reducible to the simple decanting of experience. The form his poetic descriptions take is also not like most modes of observation, if by observation we mean the distanced and disinterested contemplation of things, or the translation of objects into mental representations or epistemic judgments. Whitmanian testimony, by contrast, values the intimate coupling of the movement of one's attention with currents of activity in the environment.

Already, in Section 2 of "Song of Myself", we can see Whitman beginning to develop this mode of awareness through a descriptive art that positions him in relationship to his surroundings:

My respiration and inspiration, the beating of my heart, the

passing of blood and air through my lungs,

The sniff of green leaves and dry leaves, and of the shore and

dark-color'd sea rocks, and hay in the barn,

The sound of the belch'd words of my voice loos'd to the eddies of

the wind ... (Whitman 2004, p. 190). ${ }^{4}$

Here, Whitman oscillates between inside and outside in broad, swift movements, insinuating the thinnest of membranes dividing the two. First, he notices the feeling of anatomical processes developing in his bodily interior: his beating heart, and the passage of blood and air through his lungs. Then, Whitman pivots to what is happening outside in his environment, which he apprehends through the smell of leaves, hay, and the "dark-color'd sea rocks." In the final statement, Whitman weaves inside and outside dialectically together by noticing the sound of words as they pass from his throat of flesh into the "eddies of the wind."

By the closing lines of Section 4, Whitman contextualizes this sensual dialectic as "witnessing and waiting":

Apart from the pulling and hauling stands what I am,

Stands amused, complacent, compassionating, idle, unitary,

Looks down, is erect, or bends an arm on an impalpable

certain rest,

Looking with side-curved head curious what will come next,

Both in and out of the game and watching and wondering at it.

Backward I see in my old days where I sweated through the fog with

Linguists and contenders,

I have no mockings or arguments, I witness and wait. (Whitman 2004, p. 194) 
The stanza opens with one of the earliest self-descriptions of "Song of Myself". Who Whitman "is" stands "apart" from the forces that "pull" and "haul" at him, indicating a measure of subjective autonomy. Whitman is moved toward sympathetic openness toward others ("compassionating"), while at other times he remains unmoved, fixed, anchored in himself ("complacent" and "idle"). He shuttles back and forth between these two poles by inhabiting a kinetic state of pendular motion, swaying between ecstatic openness and centripetal inwardness.

In this sense, my reading contrasts with those for whom "Song of Myself" projects Whitman's own identity onto others in violent ways. D.H. Lawrence wrote that there was something deeply troubling about Whitman's tendency "To force his soul ... into other people's circumstances." Others find in "Crossing Brooklyn Ferry" evidence of a preference for synthesis over difference, an indication of Whitman's "Myself monomania" (See Anderson 1971; Arman 1979; Larson 1988). Tom Cohen proposes an "evil Whitman" who positions the poem's reader as "subordinate" through a rhetorical strategy of "entrapment and seduction" (Cohen 1993). Pablo Neruda, for this very reason, described Whitman as "the first totalitarian poet."

These readers tend to forget that the most common word of "Song of Myself" is not "me," or even "I," but "you." David Simpson rightly observes that we must go 500 lines into the poem before we find this ' $\mathrm{I}$ ' associated with a particular name (at least in the 1855 and the 1881 editions). Thus, according to Charles Altieri, "Specific references to any one person seem far less important than the range of functions and investments that emerge simply by observing how the pronoun gets situated within aspects of the world" (Altieri 1999, p. 36). One effect of this range of pronoun functions can be seen in the way Whitman ventriloquizes or impersonates multiple personalities. Rather than view this shape shifting poetics as an instance of reprehensible appropriation, as some scholars have suggested, Grossman has argued that "Whitman's policy was to establish a new principle of access that would effect multiplication, or pluralization (the getting many into one), without the loss entailed by exchange." 5 This pluralization effect can be seen in the way Whitman sings "himself." Rather than a self that indulges in egoistic self-absorption, Whitman expresses an elastic condition of selfhood in which one is thrown yet snaps back. An ontological boomerang.

One of the outcomes of this sense of being unmade, and then re-made out of this unmadeness, is described in the following lines of the stanza as a sense of being "both in and out of the game." His attention, figured as "watching and wondering" about the futural "what will come next," places him, at once, "in and out" of the world's domain. He is inside because he is the subject of "Looking," but he is also outside because what he is looking at ("what will come next") is yet to come. Though his watchfulness renders him ineluctably present, he is also "looking with side-curved head curious" at a future that is somehow happening yet not quite already given. Of course, the stanza also references the ways in which Whitman is responding to the past ("Backward I see in my old days ... "). Whitman contrasts his previous interest in deliberation ("mockings or arguments") with a more open yet focused mode of attention identified at the end of the stanza as witnessing and waiting ("I witness and wait"). In contrast to the staging of an argument, witnessing and waiting reveals an alert receptiveness that takes shape through the energetic push and pull of a world always coming into being.

Waiting is often associated with squandered time. One thinks of Vladimir and Estragon, the central characters of Samuel Beckett's Waiting for Godot, who wait in vain for their redeemer to arrive. Similarly, one might recall Franz Kafka's parable, "Before the Law," whose unnamed protagonist waits his entire life, "insatiably," for a gatekeeper to permit him entry "into the law," which never actually takes place. ${ }^{6}$ In both cases, critics have conflated waiting with waste since, as it turns out, the characters in these stories have postponed or otherwise suspended action, in some cases for a very long time, but gained little or nothing in return for this investment. 
This squandering, according to George Bataille, is the very condition of the possibility for sovereignty. The trace element of uncultivated excess, what he describes as "senseless loss," reveals a world beyond all utility and gloriously in surplus of use-value. This takes place when rational processes of calculation are deferred and self-consciousness hangs interrupted at a stage of "unknowing:" "sovereignty takes place as the miraculous reign of unknowing" (Bataille 1997, pp. 282-83). In Bataille's theory of sovereignty, all sense of ends and means, and for that matter all distinctions between subject and object, dissolve in an indeterminate field of interfolding communion as one becomes, as he puts it, "like water in water."

There is an element of this in Whitman. In Morton Schoolman's reading of "Song of Myself," for instance, Whitman undermines his subjectivity the moment he invokes himself: "It is time to explain myself-let us stand up." The plural pronoun discloses Whitman's identity as already multiple, and the multiplicity of the figurative 'us' is, as Schoolman observes, so vast and indeterminate that it virtually disappears in the next line: "What is known I strip away,/I launch all men and women forward with me into the Unknown" (Schoolman 2001, p. 163). ${ }^{7}$ However, though Whitmanian waiting includes a receptiveness to what Bataille refers to as the "miraculous reign of unknowing," the effect this has is not simply to cancel or otherwise neutralize self-consciousness as an experience in pure loss or self-sacrifice. Rather, Whitmanian witnessing and waiting induces an affiliative cleaving that vitalizes a nonetheless displaced self.

Sasha Pohlmann has described waiting in Whitman's poetry as an act of "futurefounding," "of designing and caring for forms and models in a time of pending action for a time to come" (Pohlmann 2015, p. 38). Indeed, in Democratic Vistas, Whitman writes that "the fruition of democracy, on aught like a grand scale, resides altogether in the future." Against Richard Rorty's suggestion that this should be contextualized in terms of a general "deferral of possibilities," Kennan Fergusson has rightly indicated that Whitman dynamically combines the immanently present with the yet-to-come. As Pohlmann explains, "One can certainly argue about how much Whitman's poetry is actually about the 'fool's paradise of hope deferred to infinitely future prospects,' but one should never ignore the significance of the performative aspect of such poetry, the futurefounding element that is present even where the future imagined in the poem seems highly unlikely to ever be actualized." Jason Frank highlights this connection in his discussion of Whitman's "aesthetic democracy": "poetry for Whitman should not aim just to accurately represent an independent reality, but to enact a new reality" (p. 205). Understood in these terms, Whitmanian waiting is not about deferring possibility in light of a hoped for future horizon. On the contrary, waiting provides a method by which things can presently be cleaved asunder.

Part of the reason for this has to do with the way Whitman's democratic arts of attention folds waiting into witnessing, an active attunement to the procreant urge of the world and its "the blessings of more life." ${ }^{8}$ Rather than passively submit, or otherwise engage in delay, Whitman's arts of attention positions witnessing and waiting as techniques for adapting to this surplus vitality. An example of this can be seen in Section 26 of "Song of Myself:"

Now I will do nothing but listen,

To accrue what I hear into this song, to let sounds contribute toward it.

I hear bravuras of birds, bustle of growing wheat, gossip of flames, clack of sticks cooking my meals,

I hear the sound I love, the sound of the human voice,

I hear all sounds running together, combined, fused or

Following. (Whitman 2004, p. 217) 
Whitman "will do nothing but listen," intimating respite. However, this "nothing" involves a dynamic responsiveness to the rich expression of emergent forms taking shape in his environment. He lists what he notices: an avian choir, the bustling of swaying wheat, the human activity of cooking around a fire, people talking, and above all else, all of these sounds mixing together in a fusional acoustic assemblage that is "combined, fused, or following." Whitman rounds out the stanza by noticing not the singularity of the sounds themselves, so much as their blending, running together, and "following." By developing an attentiveness to the way these sounds run together-not to the way the "clack of sticks" sound, for instance, but to the way the clacking contributes toward a sounding out together with other sounds-Whitman begins to notice hearing itself; that is to say, attention itself becomes an object of attention.

The effect of this meta-attention is saturating. At one point in the same section, Whitman describes the sounds as running straight through him:

Mine is no callous shell,

I have instant conductors all over me whether I pass or stoop,

They seize every object and lead it harmlessly through me, (Whitman 2004, p. 219).

His "shell" is porous. By this point in "Song of Myself," being "both in and out of the game" has placed Whitman in the position of being just barely divided from what he senses, and yet Whitman insists on the division, thus resisting chiasmatic interpretations that stress absolute reversibility, such as can be found, for instance, in the work of Maurice MerleauPonty. Though the objects he perceives are led from his sensory apparatus "harmlessly through" his body, it is clear that their trace remains spectrally "inside" him because the experience of listening fills him so fully:

I hear the chorus, it is a grand opera,

Ah, this indeed is music-this suits me.

A tenor large and fresh as the creation fills me,

The orbic flex of his mouth is pouring and filling me full. (Whitman 2004, p. 218)

Whitman hears the soundings that pervade his surroundings as though they were musical creations ("a grand opera"). The sounds pour into him, and he is "filled" up by their "chorus." This sense of being filled up—of being full of the sounds that do not merely surround or pass through, but also summon up and permeate Whitman-exemplifies the effect witnessing and waiting has when one notices not only perceivable objects, but also the sensory organs ("instant conductors") that provide the conditions of possibility for feeling immanent with such objects in the first place.

This sense of worldly absorption, brought about through witnessing and waiting, appears again in the next section, where Whitman describes what it is like to touch what is "hardly different" from himself:

Is this then touch? quivering me to a new identity,

Flames and ether making a rush for my veins,

Treacherous tip of me reaching and crowding to help them,

My flesh and blood playing out lightning to strike what is

hardly different from myself. (Whitman 2004, p. 218)

For Whitman, touch is powerfully disruptive. It is transporting, in the sense that through touch he moves, travels out, and broadens his perspectival locus. Scarcely an exercise in self-shattering, Whitman may be "hardly different" from what he touches, but the event of touch puts him in a position of guardedness, one that returns him to his subjective mooring. As pleasurable as touch can be ("I merely stir, press, feel with my fingers, and am happy"), the self-expansion it induces prompts a defensive reaction: "To touch my person to someone else's is about as much as I/can stand;" and again: "You villain touch! What 
are you doing? My breath is tight in its/throat,/Uncleanch your floodgates, you are too much for me." 9

Yet, again, this venturing away is also a return to self, except that now who Whitman is exceeds mere subjective personality and encompasses also what he perceives. He does not merely passively detect when he touches, he "seizes" objects in his field of perception, and they are "led harmlessly through [him]." The overpowering sensation of touching and being touched, for instance, fills Whitman up with a feeling of being hardly different from what he touches. The effect of this existential brimming is transporting, as he is shuttled toward a "new identity," an expansive and elastic identity that deepens attention and sharpens attachment to the world's generous ways of happening.

In this sense, one might say that, for Whitman, the experience of touch hones what Eric Santner terms a "constitutive too-muchness." For Whitman, in other words, the experience of touch is in part defined by the fact that it "includes more reality than it can contain, it bears an excess, a too-muchness of pressure" (Santner 2001, p. 8). This too-muchness of pressure cannot be done away with but, as Santner writes, it can be diverted onto one of two paths: it can be either "the agent of our engagement, or the defense against such engagement" (Santner 2001, p. 36). As Whitman illustrates, the line between the two-between the passions infusing an engagement in the world, and a defense against such engagement-is thin, pivotal, and vitalizing. An example can be found in "Song of Myself" at the start of Section 25: "Dazzling and tremendous how quick the sun-rise would kill me,/If I could not now and always send sun-rise out of me." As can be seen here, the release valve for the too-much pressure of surplus vitality is located, for Whitman, precisely in "oneself."

In a short stanza of Section 28, that again invokes the term "witness," Whitman focuses on this thin line again:

The sentries desert every other part of me,

They have left me helpless to a red marauder,

They all come to the headland to witness and assist against me.

Even if his touch will eventually place him in a guarded position, Whitman's defenses ("sentries") are initially let down, leaving him vulnerable, as he has become exposed to the pressure of the too-muchness associated with touch. Whitman describes his defenses ("They") as converging at a headland, a coastal landform shaped around a sheer drop that extends out into a body of water. Interestingly, now, his defenses are doing the witnessing, and he has become the object of what they witness ("they come ... to witness and assist against me"). It is as if, after undergoing the complex circuit of experience associated with touch, Whitman winds up witnessing his own defenses witnessing him. This puts him in an uncanny position where he is both himself, and yet somehow simultaneously not. Through witnessing what is "hardly different" from himself, Whitman has been made vulnerable to the constitutive too-muchness associated with his being both "quivered away," and yet he has become anchored to himself through the lightning strike of sudden unsettlement. The result is a self-witnessing that mirrors the meta-noticing of Section 26. This self-reflexivity, owing to his defense against too-muchness, has become a source of agency for his engagement with it.

One way to cast this agency is in terms of the Deleuzian concept of "cleaving things asunder." In his writings on aesthetics, Deleuze writes that to "really perceive," fully and artfully, one must become attached to a thing in a manner that opens it up; or, as Brian Massumi writes of Deleuze, "You have to give the thing its distances back" (Massumi 2011, p. 51). Through attachment, ironically, one is cleaved from what is nonetheless proximate. Deleuze insists that this sundering of things is altogether different from disinterestedness, if by this we mean "neutrality, or assuming a subjective posture of noncommittalness" (Massumi 2011, p. 51). Cleaving things asunder, by contrast, involves intensifying a mode of address, and an awareness deepened through a movement of estrangement, that takes place in spaces of intimacy that are also spaces of rift. When one perceives and cleaves 
asunder one "gives a thing its distance back," but this separation also includes entering into relation with what is distanced. John Paul Ricco describes this as such: "If separation is the spacing of existence, and if existence is always relational and shared, then sharing in separation is the praxis of coexistence-of being-together" (Ricco 2014, p. 1).

Some scholars have identified this cleaving in terms of the vital principle of division in Whitman's poetics. As Mark Maslan notes, Whitman mobilized division-between self/other, body/text, form/content, people/government, etc.—as an enabling condition, rather than a debilitating one. Viewing Whitman in this light involves re-examining a whole series of relationships in his poetry in which critics have traditionally seen union as the organizing principle. Following from this insight, Tyler Hagood points out that, "Whitman depicts identity as divided, with I standing in opposition to myself. This split appears in the very first line, 'I celebrate myself.' Whitman fills in the division between the objectified $I$ and the objectified myself with the action of celebration" (Hagood 2003, p. 26). ${ }^{10}$ The effusiveness of this division underscores what is so enabling about cleaving things asunder.

Whitmanian witnessing and waiting requires such cleaving, a passionate clinging to sensual experience that nonetheless includes a parting, a "parting track'd by arrival." The indeterminacy that results from having entered a space of closeness that is also one of distancing is what makes witnessing and waiting possible. In this sense, Whitmanian witnessing and waiting is a democratic art of attention that opens one up to the procreant urge of the world in ways that do not "decreate" the sovereign self so much as elasticize it, in ways that vivify the feeling of being in the midst of what is happening. ${ }^{11}$

This reading can be compared and contrasted with what Jane Bennett describes in her twin essays, "The Solar Judgment of Walt Whitman" and "Circuits of Sympathy." In the former, Bennett asks how Whitman's poem, "By Blue Ontario's Shore," might provide an alternative idiom of judgment, one that forestalls the "vengeful demand that there exist someone to hold responsible and to pay for one's suffering." In particular, Bennett performs a close and generous reading of Whitman's felicitous line, where he commends judging "not as the judge judges but as the sun falling around a helpless thing." As Bennett explains,

The poet who judges not as the judge judges becomes as magnanimous and generous as the sun, as accepting of the things he encounters as Nature is of him ... When the poet looks out on the world, he sees not fixed entities or 'dots,' but an eternity of fibers stretched out over time. This is not a landscape of individuals but of pulsating threads that are always interacting, tangling, joining, and snapping off. The poet's very self is also one of those durational threads: no longer aspiring to become a sovereign agent or even an exclusively organic entity, the poet calls forth the various potentials of his body a quivering, transversing beam of light.(Bennett 2011, p. 133)

Bennett's reading of Whitmanian judgment elides moralizing and suspends normative condemnation and instead prioritizes a "radically ecumenical kind of praise" that is aligned with a "sympathy-strung cosmos."12

The phenomenology of sympathy, which has this "nonjudgmental quality" and flows from Whitman's solar praise, is the subject of Bennett's "Whitman's Sympathies" (later adapted as "Circuits of Sympathy" in Bennett 2020). The essay focuses on Whitman's departure from Adam Smith's theory of sympathy. In his Theory of the Moral Sentiments, Smith argues that moral beings bear the imaginative capacity to "place ourselves in the situation of the other ... and become in some measure the same person with them." By contrast, Bennett focuses on the way Whitman envisions sympathy as a "more than human atmospheric force." Specifically, "Sympathy named for him not only a human mood but also currents of 'affection' circulating in the atmosphere to connect different types of beings and things." This current of affection is motivated by the "powerful allure of oneness and the thrill of letting go of the efforts required to maintain the perimeter of a self" (Bennett 2020, p. 52). 
There are many resonances between Bennett's approach to Whitman and my own, and I hope my reading can be viewed as a complement to Bennett's. In particular, I find a close connection with Bennett when she concludes by writing, "My topic, then, has been the family of terms-judgment, perception, attentiveness, materiality - that Whitman recalibrates ... Do not judge as the judge judges but be judgmental, and this means that I must relax, calm down, step back from my default course of action, and try to discern the countenances of things and their hitherto inaudible testimonies" (Bennett 2011, p. 143).

The strongest point of contrast between my reading and Bennett's, however, can be seen in the difference between an emphasis on ecstatic self-abeyance-the "thrill of letting go"-and Whitman's poetics of cleaving things asunder. Rather than stress the forsaking of subjective anchoring through relational sympathy and solar judgment, I underscore the way Whitman vividly invokes the double valence of the term "cleave," a term that expresses as much severing as clinging. The etymological origins of the term "asunder" underscores this synchronizing of union and dissolution. The phrase derives from the Old English, sundran, as in, beaming into a separate place. Yet another example of the way Whitman draws on this cleaving/sundering can be seen in the resonant line, "I ... would fetch you whoever you are flush with myself." Flushness implies an absence of blending, yet fetching suggests return rather than escape. Despite the implied intimacy of neighborly proximity, the anonymity of "whoever you are" suggests unfamiliarity and even ineffability. The result is an expression that emphasizes, at once, conviviality and thrownness. In highlighting a relational field of oneness, Bennett's democratic politics of solar sympathy intimates a respectful bond where antagonists ultimately exchange roles. The democratic politics of cleaving things asunder, by contrast, requires rupture as much as rapturous accord.

This point of contrast is made starker by fleshing out the difference between "opiated adjacency" and the democratic politics of cleaving things asunder.

\section{Democracy as Affiliative Cleaving}

Many things may induce a sense of having been set or cast aside, writes Elaine Scarry, and likewise, many things provide a sense of acute pleasure. However, the extraordinary thing about beauty is that it accomplishes both simultaneously. By prompting pleasure at one's own self-marginalization, beauty galvanizes justice, which Scarry defines in democratic terms as "the notion of distribution ... to fairness not just in the sense of loveliness of aspect but in the sense of a symmetry of everyone's relation to one another" (Scarry 1999, p. 91). In On Beauty and Being Just, Scarry argues that the beautiful produces awe and pleasure by and for justice. More specifically, beauty "intensifies the pressure we feel to repair existing injuries," and "seems to place requirements on us for attending to the aliveness or (in the case of objects) the quasi-aliveness of our world, and for entering into its protection" (Scarry 1999, pp. 57, 90, respectively). In part, writes Scarry, this is because beauty bears within itself a distributional mandate, calling upon those subject to it to extend the perceptual care brought to the beautiful object to a broader, "more capacious sphere of objects'"' (Scarry 1999, p. 82).

Beauty accomplishes this, argues Scarry, by "radically decentering" those subject to it, and by grounding a general occasion for "unselfing." Beauty "causes a cluster of feelings that normally promote the self now to fall away" (Scarry 1999, p. 113). Importantly, "It is not just that she becomes self-forgetful but that some more capacious mental act is possible: all the space formerly in the service of protecting, guarding, advancing the self (or its prestige) is now free to be in the service of something else" (Scarry 1999, p. 113). Beauty relieves the pressure to be self-centered, and elicits happiness on behalf of those condemned to this self-marginality. "A beautiful thing is not the only thing in the world that can make us feel adjacent," Scarry qualifies, "nor is it the only thing in the world that brings a state of acute pleasure. But it appears to be one of the few phenomena in the world that brings about both simultaneously" (Scarry 1999, p. 114). 
In her definition of beauty, Scarry emphasizes a number of key points. First, beauty "brings copies of itself into being" (Scarry 1999, p. 3). This is because beauty inspires an impulse toward begetting and mimetic contagion. Second, beauty gives rise to the sense that the beautiful object must be unprecedented, and is thus sacred and worthy of protection. In this sense, beauty "fills the mind and breaks all frames that give the 'never before in the history of the world' feeling" (Scarry 1999, p. 23). In this sense, beauty is "life-affirming," or "life-saving," and makes life feel "more worth living." Third, and most importantly, beauty is defined by the aesthetic symmetry beamed forth through its projection. Beautiful things appear in a balanced arrangement of parts within a structured and balanced whole. In this sense, Scarry echoes Plato, for whom beauty reflects stability and completeness, but also Augustine, who claims that beautiful things please by proportion.

This symmetry that is manifest in the beautiful object serves as an insistent placeholder for the "imperatives of distributive justice in our social arrangements," which both expresses beauty's intrinsic equanimity and also elicits democracy's core virtue. As an example, Scarry invokes the beauty of the ancient Athenian trireme ship, and in particular the principle of rhythmic equality represented by the 170 oars beating the surface of the water in measured and synchronous tempo. Scarry extols the ships whose 170 oars and 170 oarsmen could, "like a legislative assembly, be held within the small bowl of visual space of which a human perceiver is capable, and whose rhythmic striking of the water, in time with the pipeman's flute, could also be held within the finite auditory compass of a perceiver."13 By rowing in time, the oarsmen collectively compose something acoustically harmonious, and they simultaneously participate in something rapturously beyond themselves. For Scarry, the beauty of the image of the trireme ship provides an occasion for justice and fairness. As she notes in the same passage: "Beauty is pacific: its reciprocal salute to continued existence, its pact, is indistinguishable from the word for peace. And justice stands opposed to injury: injustice and injury are the same word" (Scarry 1999, p. 107).

For Scarry, the spectacle of the trireme ship provided, in this sense, the very cradle of democracy, but her vision of its beauty might just as well support a fascist aesthetics and not a democratic one. The emphasis on synchronicity and internal uniformity could be an extension of the cult of unity, energy, and purity that informs fascism and its abandonment of democratic investments. By contrast, Whitman's arts of attention resists synchronization. As has been seen, Whitmanian waiting undermines temporal synchronization, and its emphasis on passive submission. For Whitman, waiting, by contrast, is an active technique for adapting to the surplus vitality that emerges from the procreant urge of the world. The proliferation of diverse forms, spiraling off from this urge, is more suited to democracy than the aestheticized image of mass conformity.

What is more, Whitman elicits states of being that are an alternative to relational surrender. This can be seen in the way that, throughout "Song of Myself," Whitman refuses to "let go." Instead, Whitman cleaves more tightly to what is happening by witnessing the world reflected in and through sensual experience. Acts of attention, which Whitman describes as actively receptive gestures of waiting, do not impel self-withdrawal or a retreat into non-being. Rather, they convoke a broadening of the perspectival locus in light of the pressure of too-muchness brought on by cleaving things asunder. Thus, rather than enter a zone of suspension or subjective abandonment, cleaving things asunder thrusts one into the thrall of an exceptional beyond that is nonetheless immanent. The experience animates an elastic condition of quickening and release that takes place in spaces that are as distancing as they are intimate.

This relates to another point of contrast between Scarry and Whitman. Scarry is an eloquent defender of the dynamic link that connects self-abandonment and collective flourishing. Yet her notion of beauty as idealized aesthetic harmony can also be seen as neutralizing of democratic energies. Harmony engenders accord, but at the expense of dissensus. By definition, there can be no excessive or constitutive too-muchness in Scarry's theory of beauty, which is why her cognate theory of democracy focuses on mutual absolution and pacific accord. The idea that immutable differences need to be sublimated, 
and that this can be achieved through subjective aphasia is also espoused by John Rawls, who argues that justice can only be imagined from the perspective of one who forgets who one is, such that the world can be objectively envisioned through a "veil of ignorance." However, the vision of affiliative cleaving offered by Whitman's democratic arts of attention proffers an alternative. On this score, democracy does not merely entail the mutual transfer of right, or the cultivation of institutions that serve to express the general will, or the obligation to tolerate others by bracketing inexorable moral and cultural disagreements.

Each of these constitutive components underscores a vision of democracy as an exercise in self-loss. By contrast, Whitman exhibits acts of attention that both cleave the world into difference and celebrate effusive relation. The result is a democracy of attunement and interconnectivity, not tragic sacrifice of the self nor transcendent identity that absorbs difference into an idealized "I." Even as it includes quivering towards a new identity, witnessing and waiting also elicits a deepening of attachment. This is an intimacy belied by distance. However, it is not a cold distance. Rather, Whitman offers us a vast and radiant expanse flush with fugitive potential.

Funding: This research received no external funding.

Conflicts of Interest: The author declares no conflict of interest.

\section{Notes}

1 Other scholars for whom this vision of relationality, entanglement, and democratic dispossession resonates include, for example, Denise Riley, The Words of Selves: Identification, Solidarity, Irony (Palo Alto: Stanford University Press, 2000); Ewa Ziarek, An Ethics of Dissensus: Postmodernity, Feminism, and the Politics of Radical Democracy (Palo Alto, CA: Stanford University Press, 2001); Alan Keenan, Democracy in Question (Stanford University Press, 2003); Jean-Luc Nancy, The Truth of Democracy (New York: Fordham University Press, 2010); Athena Athanasiou, et al., Dispossession: The Performative in the Political (Cambridge, UK: Polity, 2013); Judith Butler, Notes Toward a Performative Theory of Assembly (Harvard University Press, 2015); and Adriana Cavarerro, Surging Democracy: Notes on Hannah Arendt's Political Thought (Palo Alto, CA: Stanford University Press, 2021).

2 For a wonderful example of the florescence of interest in Whitman amongst political theorists in general see, for instance, the excellent collection of essays in Seery (2011). For accounts of his import for democratic theory see, in particular, the chapters by George Kateb, Jason Frank, Michel Shapiro, Martha Nussbaum, Terrell Carver, Jack Turner, Morton Schoolman, and Kennan Ferguson. For a discussion of Jane Bennett's reading of Whitman, whose influential work has contributed invaluably to this literature, see below.

3 In this regard one may contrast my reading with others that focus on Whitman's stoic relationship to death. Jack Turner, for instance, emphasizes the extent to which Whitman "sought to allay readers' mortal anxiety by intimating the self's material immortality" (Turner, in Seery 2011, p. 273). Though Turner is no doubt correct, on my reading Whitman contributes to democratic thought less on the basis of a poetics of death (self-loss), and more in terms of an affirmation of life-and the procreant urge of the world—which, as will be seen, places emphasis on affiliative cleaving rather than "coolness in the face of death."

4 All references to "Song of Myself" are taken from the "death-bed" edition, which, given the introduction of sections, offers convenient citation.

5 Grossman turns to part 5 of "Song of Myself" where Whitman writes, "I believe in you my soul, the other I am not abase itself to you/And you must not be abased to the other." For Grossman, this line comprises a "rewriting of hierarchies—soul/body, collective/individual, nation/state-as equalities, and the rewriting as identities of conventional dualities, above all the self and the other, is the task of the 'translator,' whose goal is union as the fraternalization of the community" (Grossman 1982, p. 194).

6 In his generous reading of "Before the Law," James Martel argues against this interpretation by indicating that waiting in vain may not itself always be in vain. Kafka's character may wait in vain, in the sense that he never gets what he nominally wants and waits for, but he also comes to recognize that what he was waiting for has, in a sense, already arrived. Martel draws on this moment of realization in the parable and applies it more broadly to democratic politics: "More accurately, we find that the democratic practices that we seek are in fact already here; our act of waiting is what has made those practices possible in the first place, but it is not until we realize that we wait in vain that they may finally become legible to us."

7 George Kateb argues that "[Whitman's] work urges each of us to back to a solitary relation with something unconceptualizableperhaps the sheer fact of existence, of one's being and the being of anything else even and especially when 'cheaper, easier, nearer.' What makes this solitude democratic — a democratic transcendence of democratic culture-is the, as it were, philosophical self-respect ... that democracy encourages in each person and that Whitman's work tries so profoundly and so desperately to make convincing" (Kateb, in Seery 2011, p. 44). For Kateb, democratic culture, in its Whitmanian vein, is a political experience in, as Whitman himself once put it, "communing with the unutterable." However, for Kateb, this connection to the mystical 
beyond is framed as a solitary relation. This reading underestimates the affiliative side of cleaving in Whitman. It is true, in my reading, that Whitman underscores one's independent relationality to the Unknown, but this independence is always already what foregrounds human connectedness, which in turn confounds any vision of possessive individualism.

8 I borrow this phrasing from Bloom (1987, p. 161).

9 For a wonderful discussion of Whitman's poetics of touch, see Doty (2020). For fascinating conversations on the phenomenology of touch generally, see for instance, Vasseleu (1998); Derrida (2005); Nancy (2008). On the politics of this phenomenology, see especially Manning (2006). For Manning, a "politics of touch implies a spiraling politics in-creation, an eternal return to the unknowable. A politics of touch is the affirmation that we must make space and time for politics, where this space and time can exceed the current state (of affairs). Politics of touch are tactical discursive tactics of the unknowable" (Manning 2006, p. 15). On the ethics of embodied touch in the Occidental tradition, see especially Ross (1998). For an exploration of the relationship between skin and touch, see for instance MacKendrick (2004).

10 As Hagood notes, “On the one hand, Whitman positions the individual as the predominant vehicle and measuring stick of perception, judgment, and value. At the same time, he promotes fluidity, boundlessness, and connectedness characterized by ideals of democratic social equality" (p. 25).

11 Jason Frank argues that "Whitman embraced the erotics and anonymity of everyday urban encounters as the basis for envisioning-and poetically disseminating—new and less identitarian forms of political attachment" (Frank 2011, in Seery 2011, p. 157). Indeed, as William James once quipped of Whitman, "Whitman felt the human crowd as rapturously as Wordsworth felt the mountains." Though I agree with Frank that Whitman expresses forms of sociality that emphasize chance, experience, and perhaps also affect, I argue that the emphasis on anonymity underplays the importance of intimacy in Whitman. By contrast, framing Whitman's democratic arts of attention in terms of "cleaving things asunder" has the benefit of capturing both the distance (anonymity) and the simultaneous intimacy (proximity) on display in Whitman's writing.

12 In this regard Bennett's reading can be put into conversation with Martha Nussbaum's understanding of sympathy in Whitman's poetry. Nussbaum emphasizes the notion that, for Whitman, sympathy is not "facile," but can rather be compared to Lincoln's sympathy: "a sympathy with teeth, coupled with a prophetic call for this-worldly justice. Seeing eternity in men and women entails working for a society that treats every one of them as an end, and none as a mere tool for the ends of others" (Nussbaum in Seery 2011, p. 100).

13 According to Euripedes, the oarsmen "striking and sweeping the silver surface of the sea according to the pace of the piper's song, the dolphins cresting and diving to the same flashing meter, as though in fraternal salute" (Scarry 1999, p. 72).

\section{References}

Altieri, Charles. 1999. Spectacular Antispectacle: Ecstasy and Nationality in Whitman and His Heirs. American Literary History 11: 34-62. [CrossRef]

Anderson, Quentin. 1971. The Imperial Self: An Essay in American Literary and Cultural History. New York: Vintage Books.

Arman, B. 1979. Transcendence through Technique: Whitman's 'Crossing Brooklyn Ferry' and Impressionist Painting. In The Arts and Their Interrelations. Edited by Harry Garvin and James Heath. Lewisburg: Bucknell University Press, pp. 62-72.

Bataille, George. 1997. The Bataille Reader. Edited by Fred Botting and Scott Wilson. Oxford: Blackwell.

Bennett, Jane. 2011. The Solar Judgment of Walt Whitman. In A Political Companion to Walt Whitman. Edited by John Seery. Lexington: The University Press of Kentucky, pp. 131-48.

Bennett, Jane. 2020. Influx E Efflux: Writing Up with Walt Whitman. Durham: Duke University Press.

Bloom, Harold. 1987. Freud and Beyond. In Ruin the Sacred Truths: Poetry and Belief from the Bible to the Present. Cambridge: Harvard University Press.

Cohen, Tom. 1993. Only the Dead Know Brooklyn Ferry: The Inscription of the Reader in Whitman. Arizona Quarterly 49: 23-51. [CrossRef]

Derrida, Jacques. 2005. On Touching-Jean-Luc Nancy. Stanford: Stanford University Press.

Doty, Mark. 2020. What Is the Grass: Walt Whitman in My Life. New York: Norton.

Grossman, Allen. 1982. The Poetics of Union in Whitman and Lincoln: An Inquiry toward the Relationship of Art and Policy. In The American Renaissance Reconsidered. Edited by Walter Benn Michaels and Donald E. Pease. Baltimore: Johns Hopkins University Press, pp. 183-209.

Hagood, Taylor. 2003. Hair, Feet, Body, and Connectedness in “Song of Myself”. Walty Whitman Quarterly Review 21: 25-34. [CrossRef] Larson, Kerry. 1988. Whitman's Drama of Consensus. Chicago: University of Chicago Press.

MacKendrick, Karmen. 2004. Word Made Skin: Figuring Language at the Surface of Flesh. New York: Fordham University Press.

Manning, Erin. 2006. Politics of Touch: Sense, Movement, Sovereignty. Minneapolis: University of Minnesota Press.

Massumi, Brian. 2011. Semblance and Event. Cambridge: MIT Press.

Morton, Timothy. 2013. Hyperobjects: Philosophy and Ecology after the End of the World. Minneapolis: University of Minnesota Press.

Nancy, Jean-Luc. 2008. Disenclosure: The Deconstruction of Christianity. New York: Fordham University Press.

Norton, Anne. 2001. Evening Land. In Democracy and Vision: Sheldon Wolin and the Vicissitudes of the Political. Edited by Aryeh Botwinick and William Connolly. Princeton: Princeton University Press, pp. 161-70.

Nussbaum, Martha. 2001. Upheavals of Thought: The Intelligence of the Emotions. Cambridge: Cambridge University Press. 
Pohlmann, Sascha. 2015. Future-Founding Poetry: Topographies of Beginnings from Whitman to the Twenty-First Century. Rochester: Camden House.

Ricco, Jean Paul. 2014. The Decision between Us: Art and Ethics in the Time of Scenes. Chicago: University of Chicago Press.

Ross, Stephen David. 1998. The Gift of Touch: Embodying the Good. Albany: State University of New York Press.

Santner, Eric. 2001. On the Psychotheology of Everyday Life: Reflections on Freud and Rosenzweig. Chicago: University of Chicago Press.

Scarry, Elaine. 1999. On Beauty and Being Just. Princeton: Princeton University Press.

Schoolman, Morton. 2001. Reason and Horror: Critical Theory, Democracy and Aesthetic Individuality. London: Routledge.

Seery, John. 2011. A Political Companion to Walt Whitman. Louisville: The University Press of Kentucky.

Silverman, Kaja. 2015. The Miracle of Analogy. Palo Alto: Stanford University Press.

Vasseleu, Cathryn. 1998. Textures of Light: Vision and Touch in Irigaray, Levinas and Merleau-Ponty. New York: Routledge.

Whitman, Walt. 2004. Leaves of Grass: First and "Dead-Bed" Editions. New York: Barnes \& Noble Classics. 